JKM (Jurnal Kebidanan Malahayati),Vol 7,No.4.Oktober 2021,

ISSN (Print) 2476-8944 ISSN (Online) 2579-762X, Hal 801-808

\title{
PENGARUH PEMBERIAN DAUN KELOR PADA IBU HAMIL TRIMESTER III DENGAN \\ PENINGKATAN KADAR HB DI WILAYAH KERJA PUSKESMAS GEDUNG SARI KECAMATAN ANAK RATU AJI KABUPATEN LAMPUNG TENGAH
}

\author{
Yuliana Tampubolon ${ }^{1}$, Yuli yantina2 ${ }^{*}$, Devi kurniasari ${ }^{3}$, Nurul isnaini $^{4}$ \\ 1,3,4 Program Studi Kebidanan DIV Universitas Malahayati \\ 2Program Studi Kebidanan DIV Universitas Malahayati \\ *Koresponsensi email isnaininurul59@yahoo.com
}

\begin{abstract}
THE INFLUENCE OF MORINGA LEAF CONSUMPTION BY TRIMESTER II PREGNANT MOTHERS TO HEMOGLOBIN LEVEL IMPROVEMENT IN GEDUNG SARI PUBLIC HEALTH CENTER WORKING AREA IN ANAK RATU AJI SUB DISTRICT OF MIDDLE LAMPUNG DISTRICT
\end{abstract}

Background a pre-survey result to 67 trimester II and 59 trimester III pregnant mothers in Gedung Sari public health center in Anak Ratu Aji sub district of Middle Lampung district showed that 27 respondents (88\%) suffered anemia and 7 respondents (10.4\%) did not suffer anemia. After interviews to 6 pregnant mothers suffering anemia, they said never consuming moringa leaf. This attracted the author to study the moringa leaf consumption pattern related to pregnant mothers' hemoglobin levels.

The objective of this research was to find out the influence of moringa leaf consumption by trimester II pregnant mothers to hemoglobin level improvement in Gedung Sari public health center working area in Anak Ratu Aji sub district of Middle Lampung district in 2020.

Methods this was a quantitative research by using quasi-experiment approach and one group pretest and posttest design. Population was 27 trimester III pregnant mothers suffering mild and moderate anemia in Gedung Sari public health center working area in Anak Ratu Aji sub district of Middle Lampung district. Samples were of total population.

Result bivariate analysis result with paired sample t-test showed $p$-value $0.000<0.05$ meaning that there was an influence of moringa leaf consumption by trimester II pregnant mothers to hemoglobin level improvement in Gedung Sari public health center working area in Anak Ratu Aji sub district of Middle Lampung district in 2020. The average respondents' $\mathrm{Hb}$ levels before consuming moringa leaf was 8.596 with minimum and maximum scores of $8.0 \mathrm{~g} / \mathrm{dl}$ and $9.6 \mathrm{~g} / \mathrm{dl}$ respectively. The average respondents' Hb levels after consuming moringa leaf was 10.048 with minimum and maximum scores of $8.9 \mathrm{~g} / \mathrm{dl}$ and $11.4 \mathrm{~g} / \mathrm{dl}$ respectively. The difference score of $\mathrm{Hb}$ levels before and after treatment was -1.4519 .

The conclusion is that there is an effect of giving Moringa leaves to pregnant women in the third trimester of $\mathrm{Hb}$ levels in the working area of the Gedung Sari Health Center, Anak Ratu Aji District, Central Lampung Regency in 2020.

Suggestions can be used as input, evaluation and consideration to formulate/make new policies or programs in an effort to improve quality antenatal services, such as providing special facilities for mothers who will conduct counseling related to increasing $\mathrm{Hb}$ levels, as well as providing health education about the importance of Moringa leaves in increasing $\mathrm{Hb}$ levels.

Keywords : Hb level and moringa leaf

\section{ABSTRAK}

Latar Belakang Berdasarkan data survey Di Puskesmas Gedung Sari Kecamatan Anak Ratu Aji Lampung Tengah terhadap 67 ibu hamil TM III, setelah dilakukan observasi berdasarkan pemeriksaan $\mathrm{Hb}$, diketahui dari 59 ibu hamil TM III, menunjukkan 27 ibu hamil (88\%) mengalami anemia dan 7 ibu hamil (10,4\%) tidak mengalami anemia. Setelah dilakukan wawancara terhadap 6 ibu hamil yang mengalami anemia, mereka mengatakan tidak pernah mengkonsumsi daun kelor. Hal ini menarik penulis untuk menelaah lebih lanjut bagaimana pola konsumsi daun kelor dengan kadar hemoglobin pada ibu hamil. 
Tujuan dalam penelitian ini adalah untuk mengetahui pengaruh pemberian daun kelor pada ibu hamil trimester III terhadap kadar Hb Di Wilayah Kerja Puskesmas Gedung Sari Kecamatan Anak Ratu Aji Kabupaten Lampung Tengah Tahun 2020.

Metode jenis penelitian kuantitatif , rancangan Quasi Experiment dengan pendekatan one group pre test and post test design. Populasi dalam penelitian ini adalah seluruh ibu hamil TM III yang mengalami anemia ringan dan sedang di wilayah Kerja Puskesmas Gedung Sari Kecamatan Anak Ratu Aji Kabupaten Lampung Tengah tahun 2020 sampel dalam penelitian ini adalah kunjungan ibu hamil TM III perbulannya mencapai 27 ibu hamil dengan anemia ringan dan sedang. Dalam penelitian ini teknik sampling yang digunakan adalah Total Sampling.

Hasil Berdasarkan analisis bivariat dengan menggunakan uji Paired Sample T-Test, diketahui nilai p-value $<0,05$ yaitu 0,000 yang artinya Ada Pengaruh Pemberian Daun Kelor Pada Ibu Hamil Trimester III Terhadap Kadar Hb Di Wilayah Kerja Puskesmas Gedung Sari Kecamatan Anak Ratu Aji Kabupaten Lampung Tengah Tahun 2020. rata-rata kadar $\mathrm{Hb}$ responden sebelum diberikan daun kelor adalah 8,596 dengan nilai minimum 8.0 $\mathrm{g} / \mathrm{dl}$ dan maksimum 9,6 g/dl, dari 27 Responden setelah mengkonsumsi daun kelor rata-rata kadar $\mathrm{Hb}$ responden sesudah diberikan daun kelor adalah 10,048 dengan nilai minimum 8,9 g/dl dan maksimum 11,4 g/dl diketahui nilai selisih kadar $\mathrm{Hb}$ antara sebelum dan sesudah adalah $-1,4519$.

Kesimpulan ada Pengaruh Pemberian Daun Kelor Pada Ibu Hamil Trimester III Terhadap Kadar Hb Di Wilayah Kerja Puskesmas Gedung Sari Kecamatan Anak Ratu Aji Kabupaten Lampung Tengah Tahun 2020.

Saran dapat digunakan sebagai bahan masukan, evaluasi dan pertimbangan untuk menyusun/membuat kebijakan atau program baru dalam upaya peningkatan pelayanan antenatal yang berkualitas, seperti menyediakan fasilitas tempat/ruangan khusus ibu yang akan melakukan konseling terkait dengan peningkatan kadar $\mathrm{Hb}$, serta memberikan pendidikan kesehatan tentang pentingnya daun kelor dalam meningkatkan kadar $\mathrm{Hb}$.

Kata Kunci : Kadar Hb \& Daun Kelor

\section{PENDAHULUAN}

Kehamilan merupakan kondisi fisiologis, namun kenyataannya dapat timbul masalah selama proses kehamilan, salah satunya berkaitan dengan gizi. Masalah gizi yang banyak terjadi pada ibu hamil adalah anemia. Anemia pada masa kehamilan merupakan gangguan gizi sebagai akibat pola makan yang salah pada ibu hamil. Pola makan yang salah/tidak baik mengakibatkan kurangnya asupan zat gizi (Asrinah, dkk, 2010).

Anemia pada masa kehamilan dapat meningkatkan risiko kematian janin selama periode prenatal, bayi lahir sebelum waktunya, risiko perdarahan postpartum, hipertensi dan gagal jantung saat kehamilan, Berat Badan Lahir Rendah (BBLR). Sekitar 10-20\% ibu hamil di dunia mengalami anemia pada kehamilan, $75 \%$ berada di negara sedang berkembang. Prevalensi anemia ibu hamil di negara berkembang $43 \%$ dan $12 \%$ pada wanita hamil di negara maju. Kematian maternal disebabkan anemia saat kehamilan secara keseluruhan di dunia 20-40\% dari 50.000 (Willeam $\mathrm{R}, 2010$ )

Hasil penelitian menunjukkan bahwa $40 \%$ kematian ibu disebabkan perdarahan saat melahirkan dan diperkirakan $20 \%$ oleh rendahnya kadar hemoglobin (anemia gizi) selama kehamilan. Anemia gizi dapat disebabkan oleh defisiensi zat besi, asam folat, vitamin B12 dan vitamin A. Anemia gizi dalam kehamilan $75 \%$ disebabkan oleh defisiensi besi. Anemia defisiensi zat besi sering terjadi karena terdapat peningkatan kebutuhan zat besi dua kali lipat pada ibu hamil akibat peningkatan volume darah tanpa ekspansi plasma volume untuk memenuhi kebutuhan ibu dan pertumbuhan janin (Willeam R, 2010).

Menurut World Health Organization (WHO) menargetkan penurunan prevalensi anemia pada ibu hamil sebesar 50\% pada tahun 2025 (WHO, 2014), hal ini dikarenakan sejak tahun 2014-2016 prevalensi anemia pada ibu hamil selalu mengalami peningkatan \pm mencapai $12 \%$, sedangkan menurut Riskesdas 2018 menunjukkan persentase anemia pada ibu hamil khususnya pada TM III mencapai $34 \%$, berbeda dengan tahun 2017 hanya mencapai $29,7 \%$ dan tahun 2016 mencapai 27,1\% (Riskedas, 2018).

Menurut Data Dinas Kesehatan Provinsi Lampung, tahun 2017 prevalensi kejadian anemia mencapai 22,4\% dari 6.200 jumlah ibu hamil, pada tahun 2018 mencapai $20,7 \%$ dari 5.800 jumlah ibu hamil dan pada tahun 2019 prevalensi anemia meningkat kembali menjadi $23,2 \%$ dari 6.230 ibu hamil. Salah satu faktor penentu dalam angka prevalensi anemia adalah kurangnya pengetahuan 


\section{JKM (Jurnal Kebidanan Malahayati),Vol 7,No.4.Oktober 2021, \\ ISSN (Print) 2476-8944 ISSN (Online) 2579-762X, Hal 801-808}

ibu hamil tentang asupan makan yang bergizi (Profil Dinkes Provinsi Lampung, 2019).

Anemia dalam kehamilan yang disebabkan karena kekurangan zat besi, jenis pengobatannya relatif mudah bahkan murah. Darah akan bertambah banyak dalam kehamilan yang lazim disebut Hidremia atau Hipervolemia. Akan tetapi, bertambahnya sel darah kurang dibandingkan dengan bertambahnya plasma sehingga terjadi pengenceran darah. Perbandingan tersebut adalah sebagai berikut : plasma $30 \%$, sel darah $18 \%$ dan haemoglobin 19\%. Bertambahnya darah dalam kehamilan sudah dimulai sejak kehamilan 10 minggu dan mencapai puncaknya dalam kehamilan antara 32 dan 36 minggu. Secara fisiologis, pengenceran darah ini untuk membantu meringankan kerja jantung yang semakin berat dengan adanya kehamilan. Kebanyakan anemia dalam kehamilan disebabkan oleh defisiensi besi dan perdarahan akut bahkan tidak jarang keduanya saling berinteraksi. Anemia pada kehamilan dapat mengakibatkan tidak adekuatnya pengangkutan oksigen ke seluruh jaringan tubuh, sehingga ibu dengan anemia gizi defisiensi zat besi perlu diberikan zat yang dapat membentuk hemoglobin (Pribadi. A, 2015)

Anemia merupakan kekurangan zat besi dapat meningkatkan risiko terhadap ibu dan bayi. Suplementasi merupakan strategi penting dalam menanggulangi defisiensi zat gizi mikro pada wanita. Data asupan zat gizi mikro pada wanita umur 15-49 tahun yang melahirkan anak dalam 5 tahun sebelum survey berdasarkan karakteristik latar belakang. Mayoritas wanita yang melahirkan selama lima tahun sebelum survei menerima suplemen zat besi selama kehamilan untuk persalinan anak terakhir. Hanya satu dari tiga (33\%) wanita yang menerima tablet zat besi sesuai dengan rekomendasi (90 hari atau lebih), 7\% menerima 60-89 hari dan 31\% menerima kurang dari 60 hari. Kemungkinan penerimaan/asupan zat besi untuk 90 hari atau lebih meningkat seiring dengan umur, tingkatan pendidikan dan kuintil kekayaan. Wanita perkotaan jauh lebih mungkin mengambil pil zat besi setidaknya 90 hari dibanding wanita pedesaan (Pribadi. A, 2015

Kelor (Moringa oleifera Lam) banyak senyawa alami yang lebih banyak dan beragam dibanding jenis tanaman lainnya. Menurut hasil penelitian, daun kelor mengandung vitamin $A$, vitamin $B$, vitamin $C$, kalsium, kalium, besi dan protein dalam jumlah sangat tinggi yang mudah dicerna oleh tubuh manusia. Tingginya kandungan zat besi ( $\mathrm{Fe}$ ) pada daun kelor kering ataupun dalam bentuk tepung daun kelor yaitu setara dengan 25 kali lebih tinggi daripada bayam dapat dijadikan alternatif penanggulangan anemia pada ibu hamil secara alami. Kandungan senyawa kelor telah diteliti dan dilaporkan oleh dr. Zuwariyah (2014), menyebutkan bahwa daun kelor mengandung besi $28,29 \mathrm{mg}$ dalam $100 \mathrm{gram}$

Menurut penelitian Mutia Rahmawati, dkk tentang Pengaruh Ekstrak Daun Kelor Terhadap Peningkatan Kadar Hemoglobin Ibu Hamil Trimester 2 dan 3 Di Puskesmas Semanu I, menyebutkan bahwa Penelitian kuantitatif dengan desain The One Group pre-test posttest design. Tehnik sampel pada penelitian ini total sampling/total populasi sebanyak 32. Analisa data menggunakan uji statistik paired t-test. Hasil: Dengan taraf signifikasi $0,05$ diperoleh hasil $p$ value $=0,000$ ( $p$-value $<0,05)$ yang artinya ada Pengaruh. Ekstrak Daun Kelor Terhadap Peningkatan Kadar Hemoglobin Ibu Hamil Trimester 2 Dan 3 Di Puskesmas SEMANU I.

\section{METODE PENELITIAN}

Jenis penelitian kuantitatif dengan rancangan penelitian quasi eksperimen dan pendekatan one group pre test and post test design mengenai pengaruh pemberian daun kelor terhadap kadar $\mathrm{Hb}$, dengan subjek penelitian ibu hamil TM III, Populasi adalah keseluruhan objek peneliti yang akan diteliti Populasi dalam penelitian ini adalah seluruh ibu hamil TM III yang mengalami anemia ringan dan sedang Di Wilayah Kerja Puskesmas Gedung Sari Kecamatan Anak Ratu Aji Kabupaten Lampung Tengah dalam jumlah populasinya adalah 27 ibu hamil anemia ringan dan sedang Sampel penelitian adalah sebagian dari keseluruhan obyek yang diteliti dan dianggap mewakili seluruh yaitu 27 ibu hamil TM III yang mengalami anemia ringan dan sedang. Data primer diperoleh dengan wawancara menggunakan kuesioner pada ibu hamil TM III, meliputi :Karakteristik responden (umur, pendidikan, pekerjaan dan paritas).Variabel Peningkatan Kadar $\mathrm{Hb}$ diperoleh dari observasi langsung dengan responden menggunakan lembar observasi sebelum dan sesudah dilakukan perlakukan.Alat pengumpul data dalam penelitian ini menggunakan lembar observasi dan lembar SOP dalam pemberian daun kelor.Pada Analisis univariat, data yang diperoleh dari hasil pengumpulan dapat disajikan dalam bentuk tabel mean/median (Notoatmodjo, 2014). Analisis univariat dalam penelitian ini menyajikan persentase dari rata-rata peningkatakn kadar $\mathrm{Hb}$ sebelum dan sesudah diberikan daun kelor

\section{HASIL DAN PEMBAHASAN}


Berdasarkan umur Responden paling Tinggi pada usia 20 - 30 Tahun yaitu 15 ( 55,5\%) responden dan paling rendah pada usia $>30$ Tahun yaitu 12 ( 44,4\% ) Reponden

Tabel 1.

Distribusi Frekuensi Karakteristik Responden Di Wilayah Kerja Puskesmas Gedung Sari Kecamatan Anak Ratu Aji Kabupaten Lampung Tengah

\begin{tabular}{|c|c|c|}
\hline Kategori & Frekuensi & $\begin{array}{c}\text { Persentase } \\
(\%)\end{array}$ \\
\hline \multicolumn{3}{|l|}{ Umur } \\
\hline 20-30 Tahun & 15 & 55.5 \\
\hline$>30$ Tahun & 12 & 44.4 \\
\hline \multicolumn{3}{|l|}{ Pendidikan } \\
\hline D3 & 5 & 18.5 \\
\hline S1 & 1 & 3.7 \\
\hline SMA & 12 & 44.4 \\
\hline SMP & 9 & 33.3 \\
\hline \multicolumn{3}{|l|}{ Pekerjaan } \\
\hline Buruh & 2 & 7.4 \\
\hline IRT & 11 & 40.7 \\
\hline PNS & 1 & 3.7 \\
\hline Swasta & 5 & 18.5 \\
\hline Wiraswasta & 8 & 29.6 \\
\hline \multicolumn{3}{|l|}{ Paritas } \\
\hline Multigravida & 14 & 51.9 \\
\hline Primigravida & 13 & 48.1 \\
\hline Jumlah & 27 & 100.0 \\
\hline
\end{tabular}

Berdasarkan pekerjaan responden paling banyak adalah IRT ( Ibu rumaha Tangga ) yaitu sebanyak ( 40,75\% ) Responden dan paling sedikit responden mempuyai pekerjaan sebagai buruh yaitu sebanyak $2 \quad(7,4 \%)$ Responden.

Berdasarkan paritas pada responden paling banyak adalah pda kategori Multi gravida yaitu sebanyak 14 ( $51,9 \%$ ) Responden dan paling sedikit Responden pada kategori Primigravida yaitu sebanyak13 ( 48,1\%)

Rata rata Kadar $\mathrm{Hb}$ Sebelum diberikan daun Kelor

Tabel 2.

Distribusi Frekuensi status Anemia Sebelum

Pemberian Daun Kelor Pada Ibu Hamil

Trimester III Di Wilayah Kerja Puskesmas

Gedung Sari Kecamatan Anak Ratu Aji Kabupaten Lampung Tengah

\begin{tabular}{lcc}
\hline \multicolumn{1}{c}{ Anemia } & Frekuensi & Presentase \\
\hline Ringan & 22 & 81,4 \\
Sedang & 5 & 18,5 \\
\hline Total & 27 & 100 \\
\hline
\end{tabular}

Berdasarkan Tabel 2 Terli hat bahwa sebelum mengkonsumsi daun Kelor terdapat 22 ( $81,4 \%$ ) Responden berada pada kategori anemia ringan dan 5 ( 18,5 \% ) Responden berada pada anemia sedang.

Tabel 3.

Distribusi Frekuensi Rata-Rata Kadar Hb Sebelum Pemberian Daun Kelor Pada lbu Hamil Trimester III Di Wilayah Kerja Puskesmas Gedung Sari Kecamatan Anak Ratu Aji Kabupaten Lampung Tengah

\begin{tabular}{|c|c|c|c|c|c|}
\hline Variabel & $\mathbf{N}$ & Mean & Minimu & Maksimu & SE \\
\hline Kadar $\mathrm{Hb}$ & 27 & 8596 & 00 & & 01026 \\
\hline
\end{tabular}

Berdasarkan tabel 3, diketahui bahwa Di Wilayah Kerja Puskesmas Gedung Sari Kecamatan Anak Ratu Aji Kabupaten Lampung Tengah Tahun 2020 , rata-rata kadar $\mathrm{Hb}$ responden sebelum diberikan daun kelor adalah 8,596 dengan nilai minimum 8,0 dan maksimum 9,6

Rata rata Kadar $\mathrm{Hb}$ sesudah di berikan daun kelor

Berdasarkan Tabel 4 terlihat bahwa setelah mengkonsumsi daun kelor anemia sedang paling banyak yaitu 24 ( 88,8\% ) Responden dan kategori yang paling rendah tidak Anemia yaitu $3(11,1 \%)$ responden
Tabel 4.

Distribusi frekuensi status Anemia Sesudah Pemberian Daun Kelor Pada Ibu Hamil Trimester III Di Wilayah Kerja Puskesmas Gedung Sari Kecamatan Anak Ratu Aji Kabupaten Lampung Tengah

\begin{tabular}{ccc}
\hline Anemi & Frekuensi & Presentase \\
\hline Ringan & 24 & 88.8 \\
Tidak Anemia & 3 & 11.1 \\
\hline Total & 27 & 100 \\
\hline
\end{tabular}


JKM (Jurnal Kebidanan Malahayati),Vol 7,No.4.Oktober 2021,

ISSN (Print) 2476-8944 ISSN (Online) 2579-762X, Hal 801-808

Tabel 5.

Distribusi Frekuensi Rata-Rata Kadar Hb Sesudah Pemberian Daun Kelor Pada Ibu Hamil Trimester III Di Wilayah Kerja Puskesmas Gedung Sari Kecamatan Anak Ratu Aji Kabupaten Lampung Tengah

\begin{tabular}{ccccccc}
\hline Variabel & N & Mean & Minimum & Maksimum & SD & SE \\
\hline Kadar $\mathrm{Hb}$ Sesudah & 27 & 10,048 & 8,9 & 11,4 & 0,7345 & 0,1414 \\
\hline
\end{tabular}

Berdasarkan tabel 5 diketahui bahwa $\mathrm{Di}$ Wilayah Kerja Puskesmas Gedung Sari Kecamatan Anak Ratu Aji Kabupaten Lampung Tengah Tahun 2020, rata-rata kadar $\mathrm{Hb}$ responden sesudah diberikan daun kelor adalah 10,048 dengan nilai minimum 8,9 dan maksimum 11,4

\section{Analisis Bivariat}

Berdasarkan tabel 6.dapat di lihat rata rata kadar $\mathrm{Hb}$ sebelum konsumsi daun kelor kadar $\mathrm{Hb}$
8,596 dan sesudah di berikan daun kelor Kadar $\mathrm{Hb}$ , meningkat menjadi 10,048.di ketahui nilai selisih kadar $\mathrm{Hb}$ antara sebelum dan sesudah adalah 1,4519. Hasil uji pairet sample $T$ test menunjukkan nilai $P$ value 0,000 .yaitu $<0,005$ maka dapat di simpulkan ada pengaruh peningkatan kadar $\mathrm{Hb}$ sebelum dan setelah konsumsi daun kelor pada ibu.

Tabel 6.

Pengaruh Pemberian Daun Kelor Pada Ibu Hamil Trimester III Terhadap Kadar Hb Di Wilayah Kerja Puskesmas Gedung Sari Kecamatan Anak Ratu Aji Kabupaten Lampung Tengah

\begin{tabular}{ccccccc}
\hline Variabel & N & Mean & Selisih & SD & SE & P-Value \\
\hline Kadar Hb Sebelum & & 8,596 & \multirow{2}{*}{$-1,4519$} & 0,5331 & 0,1026 & \multirow{2}{*}{0,000} \\
Kadar Hb Sesudah & 27 & 10,048 & & 0,7345 & 0,1414 & \\
\hline
\end{tabular}

Uji Normalitas data

Tabel 7.

Uji Normalitas One-Sample Kolmogorov-Smirnov Test

\begin{tabular}{lll}
\hline & $\mathrm{N}$ & Unstandardized Residual \\
\cline { 3 - 3 } & & 27 \\
\hline Normal Parametersa, $\mathrm{b}$ & Mean & .0000000 \\
& Std. Deviation & .30986867 \\
Most Extreme Differences & Absolute & .091 \\
& Positive & .091 \\
& Negative & -.087 \\
Kolmogorov-Smirnov & & .472 \\
Asymp. Sig. (2-tailed) & & .979 \\
\hline
\end{tabular}

a. Test distribution is Normal.

b. Calculated from data.

Berdasarkan tabel 7 diketahui nilai $p$-value Kolmogorov-Smirnov $>0,05$, atau 0,472, sehingga data yang peneliti gunakan berdistribusi normal

\section{PEMBAHASAN}

Univariat

Karakteristik responden

Usia responden

umur ibu yang ideal dalam kehamilan yaitu pada

kelompok umur 20-35 tahun dan pada umur tersebut kurang beresiko komplikasi kehamilan serta memiliki reproduksi yang sehat.hal ini terkait dengan kondisi biologis dan psikologis dari ibu hamil sebaiknya pada kelompok umur $<20$ tahun beresiko anemia sebab pada kelompok umur tersebut perkembengan biologis yaitu reproduksi belum optimal.( Manuaba 2010 ) Selain itu kehamilan pada kelompok usia diatas 35 tahun merupakan kehamilan yang beresiko tinggi di karenakan wanita hamil pada usia ini rentan 
menderita anemia.Hal ini menyebabkan daya tahan tubuh akan menurun dan mudah terkena infeksi selama masa kehamilan ( Manuaba 2007 ) Menurut penelitian Salmariantity ( 2012 ) ibu yang hamil pada umur beresiko ( $<20$ tahun dan $>35$ tahun ) berpeluang beresiko mendapatkan anemia 1,8 kali di bandingkan ibu yg hamil pada usia tidak beresiko(20 -35 tahun)

Pendidikan Responden

Pendidikan yang dijalani seseorang memiliki pengaruh pada peningkatan kemampuan berpikir dengan kata lain seseorang yang berpendidikan lebih tinggi akan dapat mengambil keputusan yang lebih rasional,umumnya terbuka untuk menerima perubahan atau hal baru,Tingkat pendidikan ibu hamil yg rendah mempengaruhi penerimaan informasi sehingga pengetahuan tentang anemia, dan faktor faktor yang berhubungan dengan anemia menjadi terbatas terutama pengetahuan tentang pentingnya zat besi ( Budiono 2009 ).

\section{Pekerjaan Responden}

Pekerjaan ibu berkaitan dengan kejadian anemia.aktifitas yang bert akan mempengaruhi kadar haemoglobin dalam darah karena asupan oksigen di dalam tubuh.Aktifitas atau latihn ringan yang ditambah dengan suplemen asupan ntrisi akan membantu meningkatakan aksigen di dalam darah sehingga dapat menaikkan kadar hemoglobin di dalam darah( Bobak 2009)

Kebutuhan energi rata rata pada saat hamil dapat ditentukan sebesar 203 sampai $263 \mathrm{kkal} / \mathrm{hari}$ yang mengkonsumsi pertambahan berat badan 10$12 \mathrm{~kg}$ dan tidak ada perubahan tingkat kegiatan ( Arisman 2010)

Paritas Ibu

Paritas merupakan faktor yang sangat berpengaruh terhadap kejadian anemia. Mengatur jarak kehamilan atau kelahiran bayi, semakin sering seorang wanita mengalami kehamilan dan melahirkan, akan makin banyak kehilangan zat besi dan menjadi makin anemi. Jika persediaan cadangan Fe minimal, maka setiap kehamilan akan menguras persediaan $\mathrm{Fe}$ tubuh sehingga menimbulkan anemia pada kehamilan berikutnya. Oleh karena itu perlu diupayakan agar jarak antar kehamilan tidak terlalu pendek, minimal lebih dari 2 tahun (Pribadi. A, 2015).

\section{Pengaruh pemberian Daun kelor pada ibu hamil trimester III terhadap kadar $\mathrm{Hb}$}

Berdasarkan tabel 4.6.dapat di lihat rata rata kadar $\mathrm{Hb}$ sebelum konsumsi daun kelor kadar $\mathrm{Hb}$ 8,596 dan sesudah di berikan daun kelor Kadar $\mathrm{Hb}$
, meningkat menjadi 10,048.di ketahui nilai selisih kadar $\mathrm{Hb}$ antara sebelum dan sesudah adalah 1,4519. Hasil uji pairet sample $T$ test menunjukkan nilai $P$ value 0,000 yaitu $<0,005$ maka dapat di simpulkan ada pengaruh peningkatan kadar $\mathrm{Hb}$ sebelum dan setelah konsumsi daun kelor pada ibu hamil trimester III diwilayah kerja Puskesmas Gedung sari Kecamatan anak ratu Aji Kabupaten Lampung Tengah tahun 2020.

Kebutuhan zat besi di butuhkan lebih banyak ketika sedang hamil di perlukan tambahan zat besi untuk meningkatkan jumlah sel darah merah merah dan membentuk sel darah merah janin dan plasenta, kebutuhan zat besi pada setiap trimester berbeda. Terutama pada trimester kedua dan ketiga sehingga diperlukan tambahan zat besi (Suwiknyo, 2014).

Terapi oral dapat dilakukan dengan pemberian preparat besi yaitu fero sulfat, fero glukonat atau Na-fero bisirat. Pemberian preparat $60 \mathrm{mg} / \mathrm{hari}$ dapat menaikan kadar $\mathrm{Hb}$ sebanyak 1 gr\%/bulan.

Program nasional menganjurkan kombinasi $60 \mathrm{mg}$ besi dan 50 nanogram asam folat untuk profilaksis anemia (Suwiknyo, 2014).

Pada kehamilan dibutuhkan tambahan zat besi untuk meningkatkan jumlah sel darah merah dan membentuk sel darah merah janin dan plasenta, kebutuhan zat besi pada setiap trimester berbeda. Terutama pada trimester kedua dan ketiga wanita hamil memerlukan zat besi dalam jumlah banyak, oleh karena itu pada trimester kedua dan ketiga harus mendapatkan tambahan zat besi. Pencegahan anemia terutama di daerahdaerah dengan frekuensi kehamilan yang tinggi sebaiknya wanita hamil diberi sulfas ferrossus atau glukonas ferrosus, cukup 1 tablet sehari, selain itu wanita dinasihatkan untuk makan lebih banyak protein dan sayur-sayuran yang banyak mengandung mineral serta vitamin. Terapinya adalah oral (pemberian ferro sulfat $60 \mathrm{mg} / \mathrm{hari}$ menaikkan kadar $\mathrm{Hb}$ 1,00 $\mathrm{gr} \%$ dan kombinasi $60 \mathrm{mg}$ besi $+500 \mathrm{mcg}$ asam folat) dan parenteral (pemberian ferrum dextran sebanyak $1000 \mathrm{mg}$ (20 ml) intravena atau 2 × $50 \mathrm{ml}$ gr diberikan secara intramuskular pada gluteus maksimus dapat meningkatkan $\mathrm{Hb}$ relatif lebih cepat yaitu 2,00 gr\% (dalam waktu 24 jam). Pemberian parentral zat besi mempunyai indikasi kepada ibu hamil yang terkena anemia berat). Sebelum pemberian rencana parenteral harus dilakukan test alergi sebanyak $0,50 \mathrm{cc} / \mathrm{lC}$ (Suwiknyo, 2014)

Berdasarkan analisis bivariat dengan menggunakan uji Paired Sample T-Test, diketahui nilai $p$-value $<0,05$ yaitu 0,000 yang artinya $A d a$ 


\section{JKM (Jurnal Kebidanan Malahayati),Vol 7,No.4.Oktober 2021, \\ ISSN (Print) 2476-8944 ISSN (Online) 2579-762X, Hal 801-808}

Pengaruh Pemberian Daun Kelor Pada Ibu Hamil Trimester III Terhadap Kadar Hb Di Wilayah Kerja Puskesmas Gedung Sari Kecamatan Anak Ratu Aji Kabupaten Lampung Tengah Tahun 2020 diketahui bahwa 27 Responden mengalami kenaikan kadar $\mathrm{Hb}$ yaitu 24 responden masih mengalami anemia sedang dan 3 responden kadar $\mathrm{Hb}$ sudah diambang Normal,ibu hamil yang masih mengalami anemia Sedang di sebabkan karakteristik responden yang seluruhnya adalah ibu hamil trimester III di mana pada masa ini beresiko terjadinya Anemia adalah suatu kondisi dimana berkurangnya sel darah merah (eritrosit) dalam sirkulasi darah atau kadar hemoglobin tidak mampu memenuhi fungsi sebagai pembawa oksigen ke seluruh jaringan. Anemia merupakan kekurangan kualitas maupun kuantitas sel darah yang membawa oksigen di sekitar tubuh dalam bentuk hemoglobin. Hal ini menimbulkan pengurangan kapasitas sel darah merah untuk membawa oksigen bagi ibu dan janin. Anemia dalam kehamilan ialah kondisi ibu dengan kadar $\mathrm{Hb}$ $<11 \mathrm{gr} \%$ pada trimester 1 dan trimester 3 atau kadar $\mathrm{Hb}<10,5$ gram $\%$ pada trimester 2 karena terjadinya hemodilusi pada trimester II. Selama kehamilan terjadi peningkatan volume darah (hypervolemia). Hypervolemia sebagai hasil dari peningkatan volume plasma dan eritrosit (sel darah merah) yang beredar dalam tubuh. Peningkatan yang terjadi tidak seimbang, peningkatan volume plasma jauh lebih besar sehingga).

Kelor (Moringa oleifera Lam) banyak senyawa alami yang lebih banyak dan beragam dibanding jenis tanaman lainnya. Menurut hasil penelitian, daun kelor mengandung vitamin $\mathrm{A}$, vitamin $B$, vitamin $C$, kalsium, kalium, besi dan protein dalam jumlah sangat tinggi yang mudah dicerna oleh tubuh manusia. Tingginya kandungan zat besi ( $\mathrm{Fe}$ ) pada daun kelor kering ataupun dalam bentuk tepung daun kelor yaitu setara dengan 25 kali lebih tinggi daripada bayam dapat dijadikan alternatif penanggulangan anemia pada ibu hamil secara alami. Kandungan senyawa kelor telah diteliti dan dilaporkan oleh dr. Zuwariyah (2014), menyebutkan bahwa daun kelor mengandung besi $28,29 \mathrm{mg}$ dalam $100 \mathrm{gram}$.

Berdasarkan hasil penelitian diatas, maka menurut peneliti ibu hamil trimester III yang mengalami anemia dapat mengkonsumsi daun kelor untuk menikatkan kadar hemoglobin hai ini terlihat dari hasi penelitian yang sudang dilakukan pada ibu hamil trimester III dengan mengkonsumsin daun kelor selama 7 hari berturut turut tanpa putus mengalami kenaikan kadar $\mathrm{Hb} 0,8 \mathrm{gr} \%$ - 2,5 gr\% yang dapat mempengaruhi peningkatan kadar $\mathrm{Hb}$ ,.dalam penelitian ini agar ibu hamil dapat mengkonsumsi daun kelor dapat dijadikan puding sehingga responden yang tidak suka dengan bau daun kelor bisa di olah menjadi puding sehingga responden tidak bosan dalam mengkonsumsi daun kelor sebelum diberikan daun kelor kadar $\mathrm{Hb}$ responden rendah namun setelah diberikan daun kelor beberapa hari dalam penelitian, kadar $\mathrm{Hb}$ responden mengalami peningkatan, hal ini dikarenakan daun kelor mengandungvitamin $A$, vitamin $B$, vitamin $C$, kalsium, kalium, besi dan protein dalam jumlah sangat tinggi yang mudah dicerna oleh tubuh manusia, sehingga dengan kandungan tersebut maka tidak menutup kemungkinan kadar $\mathrm{Hb}$ responden dapat meningkat

\section{SIMPULAN}

Berdasarkan hasil penelitian, maka dapat disimpulkan bahwa ada Pengaruh Pemberian Daun Kelor Pada Ibu Hamil Trimester III Terhadap Kadar $\mathrm{Hb}$ Di Wilayah Kerja Puskesmas Gedung Sari Kecamatan Anak Ratu Aji Kabupaten Lampung Tengah Tahun 2020..

\section{SARAN}

Diharapkan agar dapat digunakan sebagai bahan masukan, evaluasi dan pertimbangan untuk menyusun/membuat kebijakan atau program baru dalam upaya peningkatan pelayanan antenatal yang berkualitas, seperti menyediakan fasilitas tempat/ruangan khusus ibu yang akan melakukan konseling terkait dengan peningkatan kadar $\mathrm{Hb}$, serta memberikan pendidikan kesehatan tentang pentingnya daun kelor dalam meningkatkan kadar $\mathrm{Hb}$.

\section{DAFTAR PUSTAKA}

Aprina. (2015). Riset Keperawatan. Lampung. Pendidikan Diklat Lampung.

Asrinah, dkk. (2010). Asuhan Kebidanan Masa Kehamilan. Yogyakarta: Graha IImu.

Dinas Kesehatan Provinsi Lampung. (2016). Profil Kesehatan Lampung: Bandar Lampung.

Dharma, Kusuma. (2011). Metodelogi Penelitian. Jakarta: Trans Info Media.

Hendarto.D. (2019). Khasiat Jitu Daun Kelor Dan Sirih Merah Tumpas Penyakit. Jakarta Selatan: Laksana.

Jannah, Nurul. (2012). Buku Ajar Asuhan Kebidanan: Kehamilan. Yogyakarta: Penerbit ANDI.

Kemenkes RI. 2016. Riset Kesehatan Dasar. Jakarta : Badan Penelitian Dan Pengembangan Kesehatan Kementerian Kesehatan RI. 
Lis.,Suwiknyo. (2014). Penyakit Ibu Hamil Yang Biasa Terjadi. Cara mencegah, menangani dan mengobati. Jakarta Selatan: Citra Media Pustaka.

Lawrence Green dalam Notoatmodjo. (2014). IImu Perilaku Kesehatan. Jakarta: Rineka Cipta.

Notoatmodjo, S. 2014. Metodologi Penelitian Kesehatan. Jakarta: Penerbit PT.Rineka Cipta.

Mutia Rahmawati, dkk tentang Pengaruh Ekstrak Daun Kelor Terhadap Peningkatan Kadar Hemoglobin Ibu Hamil Trimester 2 dan 3 Di Puskesmas Semanu I

Nurcahyati, Erna. (2014). Khasiat Dahsyat Daun Kelor Membasmi Penyakit Ganas. Jakarta: Jendela Sehat.
Nagtalon, Ramos. (2017). Kesehatan Ibu Dan Bayi Baru Lahir. Pedoman Untuk Perawat Dan Bidan. Jakarta: Erlangga.

Pribadi, Adi. (2015). Kehamilan Risiko Tinggi. Bandung: CV. Sagung Seto.

Profil Dinkes Provinsi Lampung. (2019). Profil Kesehatan: Lampung: Dinkes Lampung.

Profil Puskesmas Gedong Sari. (2019). Profil Puskesmas Gedong Sari. Lampung Tengah.

Riskedas. (2018). Profil Kesehatan. Jakarta: Departemen Kesehatan.

Setiadi, 2007. Konsep \& Penulisan Riset Keperawatan. Yogyakarta. Graha IImu.

Suriana. (2013). Ensiklopedia Tanaman Obat. Malang: Rumah Ide.

Willeam R \& Oxorn. (2010). IImu Kebidanan Patologi Dan Fisiologi Persalinan. Yogyakarta: C.V ANDI OFFSET 